\title{
Impact of Extended Daylight Saving Time on National Energy Consumption
}

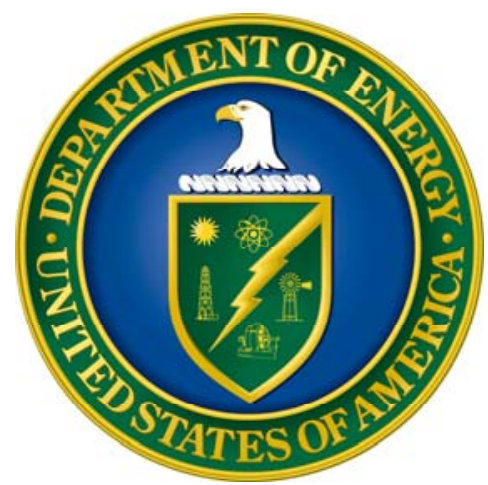

\section{Report to Congress}

Energy Policy Act of 2005, Section 110

October 2008

\section{U.S. Department of Energy}

Energy Efficiency and Renewable Energy 


\section{Acknowledgements}

The Department of Energy (DOE) acknowledges the important contributions made to this study by the principal investigators and primary authors-David B. Belzer, Ph.D (Pacific Northwest National Laboratory), Stanton W. Hadley (Oak Ridge National Laboratory), and Shih-Miao Chin, Ph.D (Oak Ridge National Laboratory). Jeff Dowd (DOE Office of Energy Efficiency and Renewable Energy) was the DOE project manager, and Margaret Mann (National Renewable Energy Laboratory) provided technical and project management assistance.

Two expert panels provided review comments on the study methodologies and made important and generous contributions.

1. Electricity and Daylight Saving Time Panel - technical review of electricity econometric modeling:

- Randy Barcus (Avista Corp)

- Adrienne Kandel, Ph.D (California Energy Commission)

- Hendrik Wolff, Ph.D (University of Washington)

2. Transportation Sector Panel - technical review of analytical methods:

- Harshad Desai (Federal Highway Administration)

- Paul Leiby, Ph.D (Oak Ridge National Laboratory)

- John Maples (DOE Energy Information Administration)

- Art Rypinski (Department of Transportation)

- Tom White (DOE Office of Policy and International Affairs)

The project team also thanks Darrell Beschen (DOE Office of Energy Efficiency and Renewable Energy), Doug Arent, Ph.D (National Renewable Energy Laboratory), and Bill Babiuch, Ph.D (National Renewable Energy Laboratory) for their helpful management review. 


\section{Executive Summary}

The Energy Policy Act of 2005 (Pub. L. No. 109-58; EPAct 2005) amended the Uniform Time Act of 1966 (Pub. L. No. 89-387) to increase the portion of the year that is subject to Daylight Saving Time. (15 U.S.C. 260a note) EPAct 2005 extended the duration of Daylight Saving Time in the spring by changing its start date from the first Sunday in April to the second Sunday in March, and in the fall by changing its end date from the last Sunday in October to the first Sunday in November. (15 U.S.C. 260a note) EPAct 2005 also called for the Department of Energy to evaluate the impact of Extended Daylight Saving Time on energy consumption in the United States and to submit a report to Congress. (15 U.S.C. 260a note)

This report presents the results of impacts of Extended Daylight Saving Time on the national energy consumption in the United States. The key findings are:

- The total electricity savings of Extended Daylight Saving Time were about 1.3 Tera Watt-hour (TWh). This corresponds to 0.5 percent per each day of Extended Daylight Saving Time, or 0.03 percent of electricity consumption over the year. In reference, the total 2007 electricity consumption in the United States was 3,900 TWh.

- In terms of national primary energy consumption, the electricity savings translate to a reduction of 17 Trillion Btu (TBtu) over the spring and fall Extended Daylight Saving Time periods, or roughly 0.02 percent of total U.S. energy consumption during 2007 of 101,000 TBtu.

- During Extended Daylight Saving Time, electricity savings generally occurred over a three- to five-hour period in the evening with small increases in usage during the earlymorning hours. On a daily percentage basis, electricity savings were slightly greater during the March (spring) extension of Extended Daylight Saving Time than the November (fall) extension. On a regional basis, some southern portions of the United States exhibited slightly smaller impacts of Extended Daylight Saving Time on energy savings compared to the northern regions, a result possibly due to a small, offsetting increase in household air conditioning usage.

- Changes in national traffic volume and motor gasoline consumption for passenger vehicles in 2007 were determined to be statistically insignificant and therefore, could not be attributed to Extended Daylight Saving Time. 
This Page left intentionally blank 


\section{Table of Contents}

Executive Summary ................................................................................... i

Table of Contents .................................................................................................. iii

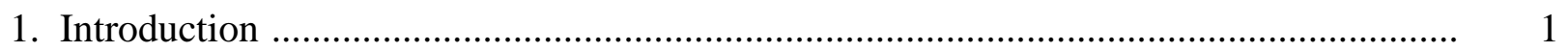

2. Key Findings: Changes in National Energy Consumption ....................................... 2

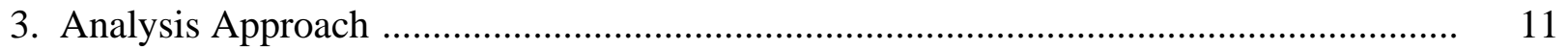

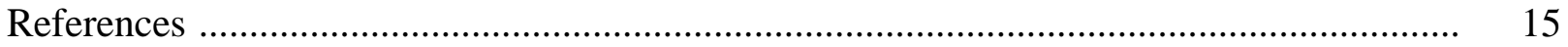

\section{List of Figures}

Figure 2-1 Average hourly electricity consumption, 2006 and 2007 spring EDST periods, Boston

Figure 2-2 Ratio of 2007 average hourly electricity consumption to 2006 average hourly consumption, Boston .................................................................. 3

Figure 3-1 Sixty-seven utilities with 2007 data overlaid on climate zone map................ 11

Figure 3-2 Illustration of heuristic approach to estimating impacts, Boston ..................... 12

\section{List of Tables}

Table 2-1 Energy Savings by Region from Electricity Reductions Using the Heuristic Method..................................................................................... 4

Table 2-2 Morning and Evening Impacts by Utility, Spring EDST.............................. 5

Table 2-3 Morning and Evening Impacts by Utility, Fall EDST …................................. 6

Table 2-4 Two-Week Average Motor Gasoline Consumption before and after

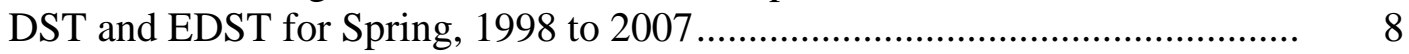

Table 2-5 Two-Week Average Motor Gasoline Consumption before and after DST and EDST for Fall, 1998 to 2007 ...................................................... 8

Table 2-6 Results from Statistical Comparison of Means........................................... 8

Table 2-7 Summary Results for Traffic from 3:00 p.m. to 9:00 p.m., Spring ................. 9 


\section{This Page left intentionally blank}




\section{Introduction}

This report presents the results of impacts of Extended Daylight Saving Time on national energy consumption in the United States. It has been prepared by the Department of Energy (DOE) in response to the requirements set forth by section 110(c) of the Energy Policy Act of 2005 (Pub. L. No. 109-58; EPAct 2005).

Section 110 of EPAct 2005 amended the Uniform Time Act of 1966 (Pub. L. No. 89-387) to increase the portion of the year that is subject to Daylight Saving Time (DST). (15 U.S.C. 260a note) EPAct 2005 extended DST in the spring from the first Sunday in April to the second Sunday in March (three or four weeks earlier than the previous law), and in the fall from the last Sunday in October to the first Sunday in November (one week later than the previous law).

Previous analyses by the Federal Government of the impact of DST on energy consumption indicated that the largest effect was on lighting (Department of Transportation, 1975; DOE, 2006). Assuming that businesses and households maintain their daily schedules (with respect to clock time) after the transition to EDST, extra evening daylight hours may lower electricity consumption because of the delayed need for lighting. Morning electricity use could increase, as people awaken to darker homes and the need for electric lighting is greater. Some parts of the country enjoy cooler or warmer evening weather, and EDST could result in changes in the amount of electricity used for heating and air conditioning.

Daylight Saving Time also provides people with the opportunity to pursue more outdoor activities during the lighter (and warmer) late-afternoon/evening hours. Consequently, while reducing electricity consumption in homes, extra daylight might lead to more driving, which would likely translate into more miles of vehicular travel, thus resulting in higher motor gasoline consumption and higher energy use.

Section 2 of this report presents the key findings on changes in electricity use, motor gasoline use, and total energy. Section 3 summarizes the analytical approaches used in the study. The detail on the analysis methods is available in the separate Technical Documentation to this report (Belzer, et al., 2008). ${ }^{1}$

\footnotetext{
${ }^{1}$ The Technical Documentation can be found on the DOE Office of Energy Efficiency and Renewable Energy's website at http://www.eere.energy.gov/ba/pba/pdfs/epact_sec_110_edst_technical_documentation_2008.pdf
} 


\section{Key Findings: Changes in National Energy Consumption}

\section{Overall National Energy Consumption Findings}

Using both heuristic ${ }^{2}$ and statistical analysis methods for measuring the national pattern of electricity changes, the study found:

- For the heuristic analysis, total savings of electricity during the four weeks of EDST time in 2007 was 1.3 TWh and the total primary energy saved associated with the changes in electricity consumption was 17 TBtu.

- For the statistical analysis, total savings of electricity during the four weeks of EDST in 2007 was 1.2 TWh. This also corresponds to a total primary energy savings of 17 TBtu. The statistical variation on this result is \pm 40 percent (at a 95 percent level of confidence).

The electricity savings are small compared to the national total for the year, representing about 0.03 percent of the total national electricity consumption of 3,900 TWh in $2007 .{ }^{3}$ On a daily basis, the total electricity savings due to EDST was 0.46 to 0.48 percent per each day of EDST.

Electricity savings generally occurred over a period of three to five hours in the evening, offset slightly by small increases in energy consumption in several morning hours-typically the hours ending at 7:00 a.m. and 8:00 a.m. in the morning, and ending 5:00 p.m. through 9:00 p.m. in the evening. On a daily percentage basis, electricity savings were slightly greater during the March (spring) extension of DST ( 0.50 percent) than the November (fall) extension ( 0.38 percent).

Regionally, areas of the southern United States exhibited smaller impacts of EDST compared to areas of the North. The study found:

- Based on the heuristic analysis, electricity savings in the South as a percent per day were the same as in the North regions, 0.48 percent.

- Based on the statistical analysis, the average daily percent savings in electricity consumption for the North were 0.51 percent, while in the South the savings were 0.42 percent.

There is insufficient statistical evidence that the EDST period has had any measurable impact on motor gasoline consumption for passenger vehicles or traffic volume in 2007.

\footnotetext{
${ }^{2}$ A pragmatic approach that compares the average changes in the pattern of electricity consumption between 2006 and 2007 during the periods of EDST in March and November without use of formal modeling.

${ }^{3}$ Total net electric load for 2006 was 3,900 TWh as reported by the North American Electric Reliability Corporation (NERC). The DOE Energy Information Administration (EIA) has projected the national total net generation for 2007 at 3,990 TWh, while consumer demand was 3,900 TWh. The differences are due to electrical losses, generation for self-use, and imports.
} 


\section{Electricity Findings}

\section{Summary of results using the heuristic method}

Available hourly electricity consumption data for periods before and after EDST in 2007 and for comparable periods in 2006 made it possible to examine visually the effect of extended daylight saving time in 2007. The study compared hourly electricity consumption for comparable periods in 2006 and 2007 for 67 regionally-representative electric utilities across the country. As an illustration of this comparison, Figure 2-1 shows the hourly electricity consumption-over the 21 days of the spring EDST period in 2007 (March 11 through March 31) -for the area

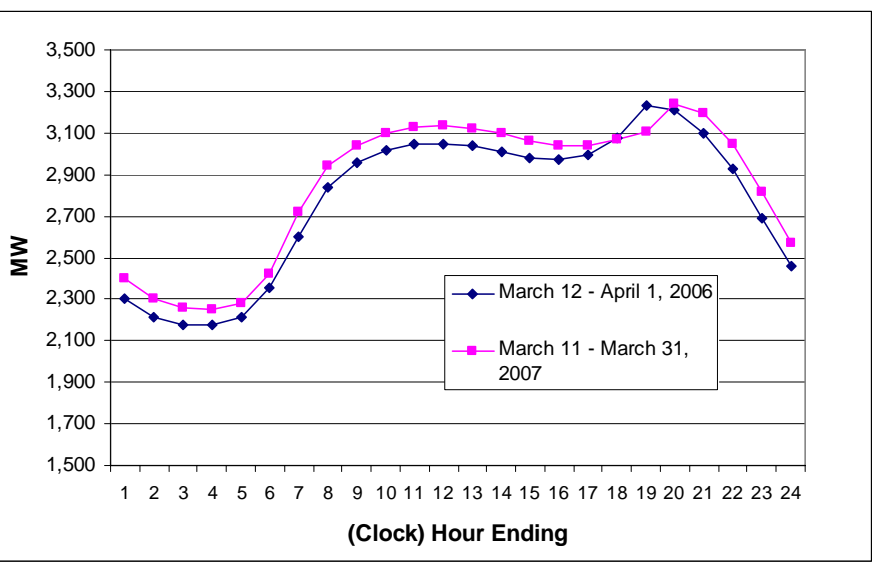

Figure 2-1. Average hourly electricity consumption, 2006 and 2007 spring EDST periods, Boston around Boston. Also shown is the electricity consumption for the same period in March of 2006. Figure 2-1 shows the average hourly consumption levels for both years. Clearly, the evening consumption in hour 19 (hour ending at 7:00 p.m.) during 2007 is relatively lower than during 2006, and the peak evening consumption in 2007 is shifted during EDST from the hour ending at 7:00 p.m. to the following hour.

Even more revealing is the ratio of the 2007 to 2006 average consumption during corresponding morning and evening EDST hours. Figure 2-2 illustrates a brief but sharp increase in the ratio of average consumption in the morning hour 7 (6:00 a.m. - 7:00 a.m.) and a prolonged reduction in electricity usage during the evening hours 17 - 21 (5:00 p.m. - 9:00 p.m.). Viewed in this manner, the reduction in electricity consumption during the evening hours appears to more than offset the increase in use during the morning hours.

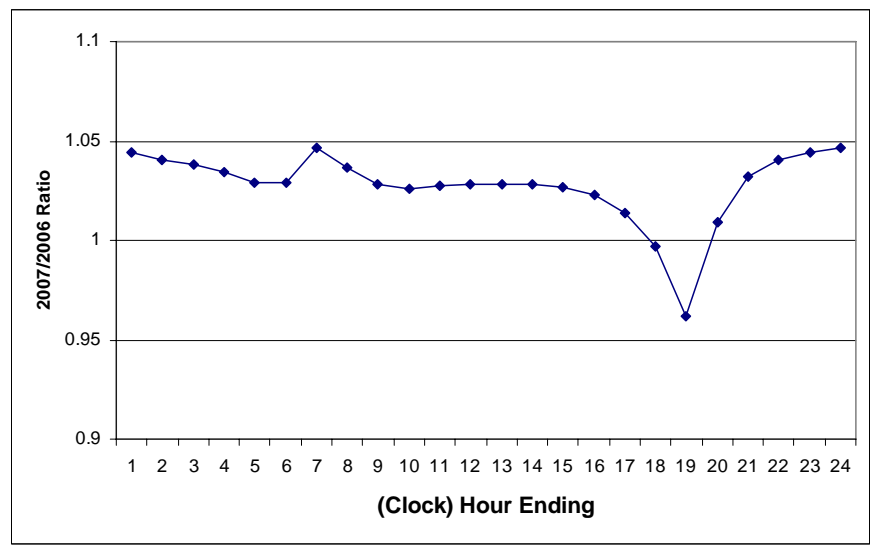

Figure 2-2. Ratio of 2007 average hourly electricity consumption to 2006 average hourly consumption, Boston

Although the ratios of electricity consumption for some utilities in this study were not as stable during the middle portion of the day as those in the Boston illustration, all of the electricity consumption curves demonstrated similar patterns. ${ }^{4}$ Variations from the clear pattern illustrated in Figure 2-1 either showed increases in morning consumption that were not as distinct or in

\footnotetext{
4 Appendix D in the supporting Technical Documentation (Belzer, et al., 2008) provides additional examples of spring and fall hourly electricity consumption curves for 19 utilities across all regions of the country.
} 
some southern regions, increased usage of air conditioning appeared to make the energy reductions during the evening occur later and with less intensity.

During the 2007 Extended Daylight Saving Time, the national average daily electricity savings, based on 16 representative regions of the North American Electric Reliability Corporation (NERC), was 0.48 percent per each day of EDST. This was the same average for the broadly aggregated Northern and Southern macro-regions. See Table 2-1. The lowest energy savings per day were in the Mid-South regions ( 0.27 percent, on average), while the greatest was in California (0.93 percent). The national daily average electricity savings were 0.48 percent per each day of EDST.

Table 2-1. Energy Savings by Region from Electricity Reductions Using the Heuristic Method ${ }^{5}$

\begin{tabular}{lcccc}
\hline NERC Region* & Location & Savings (GWH) & $\begin{array}{c}\text { Avg. Savings } \\
\text { per Day (\%) }\end{array}$ & $\begin{array}{c}\text { Primary Energy } \\
\text { Savings (TBtu) }\end{array}$ \\
\hline RFC & North & 336 & $0.46 \%$ & 5.3 \\
NPCC-NY & North & 49 & $0.41 \%$ & 0.7 \\
NPCC-NE & North & 68 & $0.68 \%$ & 0.7 \\
MRO & North & 58 & $0.37 \%$ & 0.9 \\
SERC-GAT & North & 20 & $0.36 \%$ & 0.3 \\
WECC-NWP & North & 111 & $0.64 \%$ & 1.6 \\
WECC-RMP & North & 19 & $0.43 \%$ & 0.3 \\
\hline North Subtotal & & 660 & $0.48 \%$ & 9.9 \\
\hline FRCC & South & 60 & $0.40 \%$ & 0.7 \\
SERC-DEL & South & 25 & $0.26 \%$ & 0.2 \\
SERC-SE & South & 111 & $0.67 \%$ & 1.4 \\
SERC-CEN & South & 40 & $0.29 \%$ & 0.5 \\
SERC-VAC & South & 114 & $0.52 \%$ & 1.4 \\
SPP & South & 33 & $0.24 \%$ & 0.5 \\
TRE & South & 54 & $0.29 \%$ & 0.6 \\
WECC-AZN & South & 20 & $0.61 \%$ & 0.2 \\
WECC-CNV & South & 172 & $0.93 \%$ & 2.1 \\
\hline South Subtotal & & 629 & $0.48 \%$ & 7.4 \\
\hline Total & & 1,290 & $0.48 \%$ & 17.3 \\
\hline NOte: Details on the & NERC & 519 & 0.4 \\
\hline
\end{tabular}

*Note: Details on the NERC Regions listed are found in Appendix B-1 of the supporting Technical Documentation (Belzer, et al., 2008).

\section{Summary of results using the statistical method}

For the spring 2007 EDST, energy consumption data were collected and analyzed from a core 35 utilities. See Table 2-2. The resulting data were interpolated to calculate the average percentage change in energy consumption during a daily period of two hours in the morning and five hours in the evening - typically the hours ending at 7:00 a.m. and 8:00 a.m. in the morning, and ending 5:00 p.m. through 9:00 p.m. in the evening.

\footnotetext{
${ }^{5}$ The national energy savings from electricity reduction are determined by the regional results, which are determined by scaling the individual utilities’ results within each region. Appendix B of the supporting Technical Documentation describes the construction of the weighting factors and calculation of national energy savings.
} 
Table 2-2. Morning and Evening Impacts by Utility, Spring EDST

\begin{tabular}{|c|c|c|c|c|}
\hline \multirow[b]{2}{*}{ Utility* } & \multicolumn{2}{|c|}{ Morning } & \multicolumn{2}{|c|}{ Evening } \\
\hline & $\begin{array}{c}\text { Average } \\
\text { Hourly \% Chg. }\end{array}$ & $\begin{array}{l}\text { Std. } \\
\text { Error }^{6}\end{array}$ & $\begin{array}{c}\text { Average } \\
\text { Hourly \% Chg. }\end{array}$ & $\begin{array}{l}\text { Std. } \\
\text { Error }\end{array}$ \\
\hline Indianapolis Power \& Light & $2.4 \%$ & $0.9 \%$ & $-3.8 \%$ & $1.3 \%$ \\
\hline Louisville Gas \& Elec & $1.7 \%$ & $1.0 \%$ & $-2.6 \%$ & $1.3 \%$ \\
\hline Dayton Hub - PJM & $1.6 \%$ & $0.7 \%$ & $-3.4 \%$ & $1.1 \%$ \\
\hline Duquesne Hub - PJM & $0.6 \%$ & $0.6 \%$ & $-2.6 \%$ & $0.9 \%$ \\
\hline No. Illinois Hub - PJM & $1.9 \%$ & $0.7 \%$ & $-3.6 \%$ & $0.8 \%$ \\
\hline ERCOT - Coast & $0.4 \%$ & $0.9 \%$ & $-0.8 \%$ & $1.0 \%$ \\
\hline ERCOT - S. Central & $0.5 \%$ & $1.3 \%$ & $-1.7 \%$ & $1.5 \%$ \\
\hline Con Ed - New York & $0.9 \%$ & $0.3 \%$ & $-1.9 \%$ & $0.5 \%$ \\
\hline ISO-NE - Connecticut & $1.1 \%$ & $0.6 \%$ & $-3.3 \%$ & $0.8 \%$ \\
\hline ISO-NE - NE Mass (Boston) & $1.2 \%$ & $0.5 \%$ & $-2.9 \%$ & $0.7 \%$ \\
\hline Lincoln Electric System & $1.2 \%$ & $0.8 \%$ & $-3.2 \%$ & $1.4 \%$ \\
\hline Madison Gas \& Elec & $1.8 \%$ & $0.5 \%$ & $-2.8 \%$ & $0.7 \%$ \\
\hline Otter Tail Power Co. & $4.0 \%$ & $1.6 \%$ & $-2.5 \%$ & $1.6 \%$ \\
\hline City of Tallahassee & $1.6 \%$ & $1.4 \%$ & $-2.1 \%$ & $1.3 \%$ \\
\hline Gainesville Regional Utility & $2.0 \%$ & $1.3 \%$ & $-1.8 \%$ & $1.3 \%$ \\
\hline Jacksonville Energy Authority & $1.4 \%$ & $1.2 \%$ & $-2.2 \%$ & $1.5 \%$ \\
\hline Entergy Corp. & $1.1 \%$ & $0.8 \%$ & $-1.9 \%$ & $1.4 \%$ \\
\hline Alabama Electric Coop & $-0.1 \%$ & $1.9 \%$ & $-1.2 \%$ & $2.3 \%$ \\
\hline Oglethorpe Power Co. & $0.7 \%$ & $1.7 \%$ & $-1.7 \%$ & $1.8 \%$ \\
\hline Electric Power - Chattanooga & $0.3 \%$ & $1.2 \%$ & $-2.8 \%$ & $1.3 \%$ \\
\hline Memphis Light, Gas \& Water & $1.9 \%$ & $0.9 \%$ & $-2.2 \%$ & $1.4 \%$ \\
\hline Dominion Hub - PJM & $0.6 \%$ & $1.3 \%$ & $-3.1 \%$ & $1.3 \%$ \\
\hline Ameren Control Area & $1.7 \%$ & $0.8 \%$ & $-3.1 \%$ & $1.1 \%$ \\
\hline Kansas City Public Utilities & $1.2 \%$ & $1.0 \%$ & $-1.2 \%$ & $1.3 \%$ \\
\hline Southwestern Publc Service & $0.6 \%$ & $0.7 \%$ & $-1.0 \%$ & $1.1 \%$ \\
\hline Western Farmers Elec Coop & $-0.2 \%$ & $1.4 \%$ & $-2.5 \%$ & $1.7 \%$ \\
\hline El Paso Electric & $2.6 \%$ & $0.9 \%$ & $-2.2 \%$ & $1.0 \%$ \\
\hline Public Service of N. Mexico & $2.2 \%$ & $0.6 \%$ & $-4.1 \%$ & $0.6 \%$ \\
\hline California ISO & $1.7 \%$ & $0.5 \%$ & $-4.0 \%$ & $0.6 \%$ \\
\hline Los Angeles DWP & $2.4 \%$ & $0.6 \%$ & $-3.7 \%$ & $0.9 \%$ \\
\hline Avista Corp & $1.1 \%$ & $0.7 \%$ & $-2.8 \%$ & $0.9 \%$ \\
\hline Portland General Electric & $0.6 \%$ & $0.8 \%$ & $-1.9 \%$ & $0.9 \%$ \\
\hline Chelan County PUD & $2.1 \%$ & $0.8 \%$ & $-1.0 \%$ & $0.8 \%$ \\
\hline Black Hills Corporation & $1.0 \%$ & $1.1 \%$ & $-3.5 \%$ & $1.5 \%$ \\
\hline WAPA - Rocky Mountain & $1.9 \%$ & $0.7 \%$ & $-3.3 \%$ & $0.8 \%$ \\
\hline
\end{tabular}

${ }^{*}$ Note: The utilities listed are a combination of individual utilities (investor-owned or consumer-owned) and regional entities -- Independent System Operators, or ISOs. Details are provided in Appendix B.1 of the supporting Technical Documentation (Belzer, et al., 2008).

The national average reduction in daily electricity consumption in the spring EDST period was 0.50 percent. There were substantial variations reported among utilities for both the morning and evening hours. Morning impacts ranged from a usage reduction of 0.2 percent to an increase of 4.0 percent, $^{7}$ while reductions during the evening hours generally were within the range of 1.0 to

\footnotetext{
6 "Std Error" is the standard deviation associated with the estimated change in electricity use, based upon the results of the statistical model. It is a statistical measure that reflects the uncertainty of the estimated change with respect to its expected (or average) value (as shown in the highlighted columns of Tables 2-2 and 2-3).

${ }^{7}$ The morning increases in usage reflect the compounding impact of factors other than lighting.
} 
4.0 percent. Table 2-2 summarizes the spring results from the statistical model.

The study collected and analyzed energy consumption data from a core 29 utilities for EDST in the fall of 2007. The fall EDST national average reduction in daily electricity consumption was 0.38 percent. Table 2-3 summarizes the fall EDST results from the statistical model.

Table 2-3. Morning and Evening Impacts by Utility, Fall EDST

\begin{tabular}{|c|c|c|c|c|}
\hline \multirow[b]{3}{*}{ Utility* } & \multicolumn{2}{|c|}{ Morning } & \multicolumn{2}{|c|}{ Evening } \\
\hline & Average & & Average & \\
\hline & Hourly \% Chg. & Std. Error & Hourly \% Chg. & Std. Error \\
\hline Indianapolis Power \& Light & $2.3 \%$ & $1.1 \%$ & $-3.4 \%$ & $1.9 \%$ \\
\hline Louisville Gas \& Elec & $1.4 \%$ & $1.6 \%$ & $-3.9 \%$ & $1.4 \%$ \\
\hline Dayton Hub - PJM & $0.5 \%$ & $1.1 \%$ & $-3.6 \%$ & $1.4 \%$ \\
\hline Duquesne Hub - PJM & $0.5 \%$ & $1.0 \%$ & $-3.1 \%$ & $1.3 \%$ \\
\hline No. Illinois Hub - PJM & $2.0 \%$ & $0.6 \%$ & $-3.2 \%$ & $1.0 \%$ \\
\hline ERCOT - Coast & $2.9 \%$ & $1.1 \%$ & $-1.1 \%$ & $1.3 \%$ \\
\hline ERCOT - S. Central & $3.3 \%$ & $2.4 \%$ & $-1.7 \%$ & $2.5 \%$ \\
\hline Con Ed - New York & $1.3 \%$ & $0.7 \%$ & $-1.4 \%$ & $0.7 \%$ \\
\hline ISO-NE - Connecticut & $0.5 \%$ & $1.0 \%$ & $-3.5 \%$ & $1.2 \%$ \\
\hline ISO-NE - NE Mass (Boston) & $1.0 \%$ & $0.8 \%$ & $-2.8 \%$ & $1.1 \%$ \\
\hline Lincoln Electric System & $2.9 \%$ & $0.8 \%$ & $-2.5 \%$ & $1.3 \%$ \\
\hline Madison Gas \& Elec & $1.0 \%$ & $0.6 \%$ & $-2.6 \%$ & $1.2 \%$ \\
\hline Otter Tail Power Co. & $0.9 \%$ & $2.4 \%$ & $-2.5 \%$ & $2.5 \%$ \\
\hline City of Tallahassee & $-0.2 \%$ & $1.6 \%$ & $-1.0 \%$ & $1.4 \%$ \\
\hline Gainesville Regional Utility & $1.1 \%$ & $1.5 \%$ & $-1.3 \%$ & $1.9 \%$ \\
\hline Jacksonville Energy Authority & NA & NA & $0.0 \%$ & $0.0 \%$ \\
\hline Progress Energy (Florida) & $0.6 \%$ & $1.5 \%$ & $-1.5 \%$ & $1.8 \%$ \\
\hline Entergy Corp. & $1.8 \%$ & $1.0 \%$ & $-1.7 \%$ & $1.1 \%$ \\
\hline Alabama Electric Coop & NA & NA & $0.0 \%$ & $0.0 \%$ \\
\hline Oglethorpe Power Co. & $\mathrm{NC}$ & NC & $-1.4 \%$ & $2.0 \%$ \\
\hline Electric Power - Chattanooga & $1.3 \%$ & $1.4 \%$ & $-3.1 \%$ & $1.7 \%$ \\
\hline Memphis Light, Gas \& Water & $0.7 \%$ & $1.1 \%$ & $-3.5 \%$ & $1.6 \%$ \\
\hline Dominion Hub - PJM & $0.3 \%$ & $1.8 \%$ & $-3.7 \%$ & $1.3 \%$ \\
\hline Ameren Control Area & NA & NA & $0.0 \%$ & $0.0 \%$ \\
\hline Kansas City Public Utilities & $1.7 \%$ & $1.3 \%$ & $-1.3 \%$ & $1.3 \%$ \\
\hline Southwestern Publc Serv. & NA & NA & $0.0 \%$ & $0.0 \%$ \\
\hline Western Farmers Elec Coop & NA & NA & $0.0 \%$ & $0.0 \%$ \\
\hline El Paso Electric & $1.8 \%$ & $1.7 \%$ & $-3.2 \%$ & $1.2 \%$ \\
\hline Public Service of N. Mexico & $1.8 \%$ & $0.7 \%$ & $-3.3 \%$ & $0.9 \%$ \\
\hline California ISO & $1.2 \%$ & $0.8 \%$ & $-3.8 \%$ & $1.4 \%$ \\
\hline Los Angeles DWP & $2.5 \%$ & $0.5 \%$ & $-3.6 \%$ & $0.9 \%$ \\
\hline Avista Corp & $1.0 \%$ & $1.0 \%$ & $-3.0 \%$ & $1.2 \%$ \\
\hline Portland General Electric & NA & NA & $0.0 \%$ & $0.0 \%$ \\
\hline Chelan County PUD & $1.4 \%$ & $1.3 \%$ & $-1.5 \%$ & $1.2 \%$ \\
\hline Black Hills Corporation & NA & NA & $0.0 \%$ & $0.0 \%$ \\
\hline WAPA - Rocky Mountain & $2.0 \%$ & $1.0 \%$ & $-3.7 \%$ & $0.9 \%$ \\
\hline $\begin{aligned} \text { Note: } & \text { NA } \\
& =\text { Fall data unavaila } \\
N C & =\text { Not calculated }\end{aligned}$ & & & & \\
\hline
\end{tabular}

* Note: The utilities listed are a combination of individual utilities (investor-owned or consumer-owned) and regional entities -- Independent System Operators, or ISOs. Details are provided in Appendix B.1 of the supporting Technical Documentation (Belzer, et al., 2008). 
An examination of the impact in both the morning and evening indicates that the impacts (both positive and negative) were generally smaller in the fall than in the spring. ${ }^{8}$ The national average reduction in daily electricity consumption in the fall EDST period was 0.38 percent as compared to the 0.50 percent for the spring.

\section{Transportation Energy Findings}

Changes in national traffic volume and motor gasoline consumption for passenger vehicles in 2007 could not be attributed to EDST. This finding was based on a comparison of the 2007 twoweek average national motor gasoline consumption during the weeks before and after DST and EDST. It was also based on an analysis of daily traffic volume for the late-afternoon/evening hours, 3:00 p.m. to 9:00 p.m. - when EDST was expected to have the greatest influence on gasoline use.

\section{Results from analysis of changes in motor gasoline consumption}

The changes in motor gasoline consumption due to daylight hours were small. ${ }^{9}$ The differences in mean values (averages) of "motor gasoline supplied" information were determined to be statistically insignificant for both the spring and fall over a 10-year period ranging from 1998 to 2007. "Motor gasoline supplied" is used as a proxy for motor gasoline consumption. ${ }^{10}$

Tables 2-4, 2-5, and 2-6 show the motor gasoline consumption before and after periods of Daylight Saving Time. Changes in motor gasoline consumption ranged from -3.85 percent to 3.79 percent in the spring to -3.39 percent to 3.33 percent in the fall. The 10 -year average was 0.83 percent for the spring and 0.25 percent for the fall. Table 2-6 reports the results from the statistical comparison of means for motor gasoline consumption, and it indicates the change in means is not statistically significant.

\footnotetext{
${ }^{8}$ This finding may result from two factors. First, even under standard time, some portion of the morning hours during which many people prepare for work or school is already dark at the end of October. Thus, the extension of daylight time, which provides later sunrises in terms of clock time, is expected to have a smaller effect on lighting use than in March. Second, the cooler (colder) temperatures at the end of October are less conducive to outdoor activities (e.g., gardening, youth sports activities, etc.) regardless of daylight conditions. Thus, a smaller impact on energy use for lighting in the evening during the fall EDST period, as compared to the spring, is not unexpected.

${ }^{9}$ Small compared to the seasonal variations and long-term growth rate in "motor gasoline supplied."

${ }^{10}$ In a longer timeframe, “gasoline supplied” equals gasoline consumption, provided that the motor gasoline rolling stock remains constant. DOE's EIA states: "Products supplied approximately represent consumption of petroleum products because it measures the disappearance of these products from primary sources, i.e., refineries, natural gas processing plants, blending plants, pipelines, and bulk terminals. In general, the product supplied value of each product in any given period is computed as follows: field production, plus refinery production, plus imports, plus unaccounted for crude oil, (plus net receipts when calculated on a Petroleum Administration for Defense (PAD) District basis), minus stock change, minus crude oil losses, minus refinery inputs, minus exports.” [EIA Weekly Petroleum Status Report, 2008]
} 
Table 2-4. Two-Week Average Motor Gasoline Consumption before and after DST and EDST for Spring, 1998 to 2007

\begin{tabular}{|c|c|c|c|c|}
\hline \multicolumn{2}{|c|}{ Two-Week Average Before } & \multicolumn{2}{|c|}{ Two-Week Average After } & \multirow[b]{2}{*}{$\begin{array}{l}\text { Percent } \\
\text { Change }\end{array}$} \\
\hline Two-Week Period & $\begin{array}{c}\text { Thousand Barrels } \\
\text { per Day }\end{array}$ & Two-Week Period & $\begin{array}{c}\text { Thousand Barrels } \\
\text { per Day }\end{array}$ & \\
\hline 21-Mar-98 to 3-Apr-98 & 8,494 & 4-Apr-98 to 17-Apr-98 & 8,167 & $-3.85 \%$ \\
\hline 20-Mar-99 to 2-Apr-99 & 8,148 & 4-Apr-99 to 16-Apr-99 & 7,972 & $-2.16 \%$ \\
\hline 18-Mar-00 to 31-Mar-00 & 8,140 & 1-Apr-00 to $14-A p r-00$ & 8,606 & $5.72 \%$ \\
\hline 17-Mar-01 to 30-Mar-01 & 8,491 & 31-Mar-01 to 13-Apr-01 & 8,372 & $-1.40 \%$ \\
\hline 23-Mar-02 to 5-Apr-02 & 8,626 & 6-Apr-02 to 19-Apr-02 & 8,762 & $1.58 \%$ \\
\hline 22-Mar-03 to 4-Apr-03 & 8,371 & 5-Apr-03 to 18-Apr-03 & 8,689 & $3.79 \%$ \\
\hline 20-Mar-04 to 2-Apr-04 & 8,990 & 3-Apr-04 to 16-Apr-04 & 9,156 & $1.84 \%$ \\
\hline 19-Mar-05 to 1-Apr-05 & 9,085 & 2-Apr-05 to 15-Apr-05 & 9,130 & $0.49 \%$ \\
\hline 18-Mar-06 to 31-Mar-06 & 9,059 & 1-Apr-06 to 14-Apr-06 & 9,199 & $1.55 \%$ \\
\hline 24-Feb-07 to 9-Mar-07 & 9,175 & 10-Mar-07 to 23-Mar-07 & 9,245 & $0.77 \%$ \\
\hline Average & 8,658 & & 8,730 & $0.83 \%$ \\
\hline
\end{tabular}

Table 2-5. Two-Week Average Motor Gasoline Consumption before and after DST and EDST for Fall, 1998 to 2007

\begin{tabular}{|c|c|c|c|c|}
\hline \multicolumn{2}{|c|}{ Two-Week Average Before } & \multicolumn{2}{|c|}{ Two-Week Average After } & \multirow[b]{2}{*}{$\begin{array}{l}\text { Percent } \\
\text { Change }\end{array}$} \\
\hline Two-Week Period & $\begin{array}{c}\text { Thousand Barrels } \\
\text { per Day }\end{array}$ & Two-Week Period & $\begin{array}{l}\text { Thousand } \\
\text { Barrels per Day }\end{array}$ & \\
\hline $10-O c t-98$ to $23-O c t-98$ & 8,074 & 24-Oct-98 to 6-Nov-98 & 8,278 & $-3.85 \%$ \\
\hline $16-O c t-99$ to $29-O c t-99$ & 8,527 & $30-O c t-99$ to $12-N o v-99$ & 8,375 & $-2.16 \%$ \\
\hline $14-O c t-00$ to $27-O c t-00$ & 8,773 & $28-O c t-00$ to $10-N o v-00$ & 8,498 & $5.72 \%$ \\
\hline $13-O c t-01$ to $26-O c t-01$ & 8,661 & 27-Oct-01 to 9-Nov-01 & 8,784 & $-1.40 \%$ \\
\hline $12-O c t-02$ to $25-O c t-02$ & 8,838 & $26-$ Oct-02 to $8-N o v-02$ & 9,042 & $1.58 \%$ \\
\hline $11-O c t-03$ to $24-O c t-03$ & 9,084 & 25-Oct-03 to 7-Nov-03 & 9,156 & $3.79 \%$ \\
\hline $16-O c t-04$ to $29-O c t-04$ & 8,930 & $30-O c t-04$ to $12-N o v-04$ & 9,227 & $1.84 \%$ \\
\hline $15-O c t-05$ to $28-O c t-05$ & 9,013 & 29-Oct-05 to $11-N o v-05$ & 9,199 & $0.49 \%$ \\
\hline $14-O c t-06$ to $27-O c t-06$ & 9,505 & $28-O c t-06$ to $10-N o v-06$ & 9,183 & $1.55 \%$ \\
\hline 20-Oct-07 to 2-Nov-07 & 9,361 & 3-Nov-07 to $16-N o v-07$ & 9,205 & $0.77 \%$ \\
\hline Average & 8,877 & & 8,895 & $0.25 \%$ \\
\hline
\end{tabular}

Table 2-6. Results from Statistical Comparison of Means

\begin{tabular}{lccc}
\hline & $\begin{array}{c}\text { Mean of Changes in } \\
\text { Two-Week Average Motor } \\
\text { Gasoline Consumption* }\end{array}$ & $\begin{array}{c}\text { Standard Error of the } \\
\text { Mean Change }\end{array}$ & $\begin{array}{c}\text { Change in Means: } \\
\text { Statistically Significant } \\
\text { (Yes/No) }\end{array}$ \\
\hline Spring & 72 & 74 & No \\
Fall & 18 & 71 & No \\
\hline
\end{tabular}

* Note: Unit of measurement is thousand barrels per day. 
Results for changes in late-afternoon/evening traffic volume

A statistical analysis of daily traffic volume for the late-afternoon/evening hours (3:00 p.m. to 9:00 p.m.) when EDST is expected to have the greatest influence on gasoline use shows a statistically significant, but small 0.17 percent increase in traffic volume during those hours for the week of "March 11 - March 17" (the first week of EDST) relative to "March 4 - March 10." This is shown in Table 2-7.

Table 2-7. Summary Results for Traffic from 3:00 p.m. to 9:00 p.m., Spring

\begin{tabular}{|c|c|c|c|c|c|c|}
\hline Year & Region* & $\begin{array}{l}\text { Week-to-Week Comparison for } \\
\text { Two Weeks Before and Two } \\
\text { Weeks After EDST }\end{array}$ & $\begin{array}{c}\text { Mean } \\
\text { Change } \\
\text { in Traffic } \\
\text { Volume } \\
\end{array}$ & $\begin{array}{c}\text { Standard } \\
\text { Error of } \\
\text { the Mean } \\
\text { Change } \\
\end{array}$ & $\begin{array}{l}\text { Percent } \\
\text { Change } \\
\end{array}$ & $\begin{array}{c}\text { Difference } \\
\text { in Means, } \\
\text { Statistically } \\
\text { Significant } \\
\text { (Yes/No) }\end{array}$ \\
\hline \multirow{3}{*}{2007} & \multirow{3}{*}{$\begin{array}{l}\text { United } \\
\text { States } \\
\text { (exclude } \\
\text { AZ, DC, } \\
\text { HI, WY) }\end{array}$} & $\begin{array}{l}\text { Week of "Feb } 25 \text { - Mar 3" } \\
\text { compared to "Mar } 4 \text { - Mar 10" }\end{array}$ & 157 & 6 & $1.68 \%$ & Yes \\
\hline & & $\begin{array}{l}\text { Week of "Mar } 4-\text { Mar 10" } \\
\text { compared to "Mar } 11-\text { Mar 17" }\end{array}$ & 16 & 7 & $0.17 \%$ & Yes \\
\hline & & $\begin{array}{l}\text { Week of "Mar } 11 \text { - Mar 17" } \\
\text { compared to "Mar 18-Mar 24" }\end{array}$ & -7 & 6 & $-0.08 \%$ & No \\
\hline \multirow{3}{*}{2006} & \multirow{3}{*}{$\begin{array}{l}\text { United } \\
\text { States } \\
\text { (exclude } \\
\text { AZ, DC, } \\
\text { HI, WY) }\end{array}$} & $\begin{array}{l}\text { Week of "Feb } 25-\text { Mar 3" } \\
\text { compared to "Mar } 4-\text { Mar 10" }\end{array}$ & 32 & 5 & $0.34 \%$ & Yes \\
\hline & & $\begin{array}{l}\text { Week of "Mar } 4-\text { Mar 10" } \\
\text { compared to "Mar } 11-\text { Mar 17" }\end{array}$ & 89 & 5 & $0.91 \%$ & Yes \\
\hline & & $\begin{array}{l}\text { Week of "Mar } 11-\text { Mar 17" } \\
\text { compared to "Mar 18-Mar 24" }\end{array}$ & -50 & 5 & $-0.51 \%$ & Yes \\
\hline
\end{tabular}

*Note: Arizona (AZ) and Hawaii (HI) are two states that do not observe Daylight Saving Time. Traffic volume data was not available for the District of Columbia (DC) and Wyoming (WY).

Because the late-afternoon/evening traffic accounts for about 37 percent of total traffic, the 0.17 percent increase in traffic is equivalent to a 0.06 percent increase of the daily total traffic. ${ }^{11}$ This 0.06 percent increase in daily traffic translates to a "maximum possible" motor gasoline consumption increase of about 5.5 thousand barrels per day for each day of EDST. ${ }^{12}$ The United States consumed an average of 8,800 thousand barrels of motor gasoline per day for passenger vehicles from 1998 to 2007.

However, the small increase (0.17 percent) in traffic, before and after the EDST in 2007, could not directly be attributed to EDST in 2007 for the following reasons:

\footnotetext{
${ }^{11}$ Based on the traffic information by hours of the day for some 4000 traffic counters, the traffic from 3:00 p.m. to 9:00 p.m. was about 37 percent of the total daily traffic for 24 hours for all counters during the week of March 4 to March 10, 2007. Thirty-seven percent of 0.17 percent equals 0.06 percent.

${ }^{12}$ More traffic volume will yield more motor gasoline consumption, provided the traffic volume increases are uniform among roadway segments, and the roadway segment lengths and average gasoline consumption rate are constant. The daily total traffic increase is assumed to be uniformly distributed. Weekly "motor gasoline supplied" was 9,158 thousand barrels per day for the week ending just before the start of EDST on March 11, 2007. Therefore, 0.06 percent of 9,158 thousand barrels is 5.5 thousand barrels per day.
} 
- Other factors may have influenced the changes in daily traffic volume during those hours (e.g., weather conditions, roadway construction, traffic accidents/incidents, and special events/festivals). ${ }^{13}$

- As shown in Table 2-7, there is a statistically noticeable change in traffic the week prior to EDST, when traffic increased by 1.68 percent from the week of "February 25 March 3" compared to "March 4 - March 10." In addition, there is no statistically significant difference from the week of "March 11 - March 17" to "March 18 March 24" (the second week after EDST).

- Table 2-7 also shows that the week-to-week traffic differences are statistically noticeable for the same time frame in 2006-the February 25 to March 24 period. Although these four weeks of traffic in 2006 were not under the influence of EDST, the week to week traffic differences ranged from -0.51 percent to 0.91 percent. This further supports the evidence that observed traffic variations in 2007 were the result of an array of traffic influencing factors and cannot be attributed to EDST.

Changes in national traffic volume and motor gasoline for the fall EDST

This study did not examine national traffic data for the fall of 2007. However, the miles of vehicular travel information from Traffic Volume Trends by the Federal Highway Administration shows a steady pattern of annual miles of vehicular travel for 2005, 2006, and 2007. Based on this information and expert opinion, EDST-induced traffic and associated motor gasoline consumption for the fall, if any, would likely be similar to results found in the spring.

\footnotetext{
${ }^{13}$ Gasoline prices did not appear to have been one of the factors. The average retail gasoline price was determined to not have had an influence on the week-to-week differences in traffic volume in the spring of 2007 (February 26 to March 19) and in the spring of 2006 (February 27 to March 20). During those 2007 and 2006 periods, the national weighted average retail price for all grades and all formulations of gasoline ranged from 2.43 to 2.62 dollars per gallon (February 26 to March 19, 2007) and from 2.30 to 2.55 dollars per gallon (February 27 to March 20, 2006). There was no statistical relationship between traffic volume and retail gasoline price, as measured by the correlation coefficient of 0.005 . Therefore, gasoline price was not a factor in explaining the short-term changes in traffic from February 26 to March 19 of 2007.
} 


\section{Analysis Approach}

Due to the complex interaction between additional DST hours, hourly temperature, weather, and other factors, there is no single best method for analyzing EDST impacts on electricity and motor gasoline consumption. Therefore, the study used multiple methods to evaluate the impact of EDST on changes in energy consumption, each with different strengths and limitations. Taken together, their findings provide greater insight into EDST energy impacts than would be possible by application of only a single method. The supporting Technical Documentation to this report provides details on the data and analysis methods used in the study.

\section{Analysis of Changes in Electricity Use across Extended Daylight Saving Time Transitions}

The study used two methods to calculate changes in national energy consumption associated with electricity consumption.

- A "heuristic" method compared the average changes in the pattern of electricity consumption between 2006 and 2007 during the periods of EDST in March and November.

- A statistical method applied regression models to daily and hourly consumption for a sample of utilities. ${ }^{14}$

The electricity analysis portion of the study used 2006 and 2007 consumption data from as many as 67 electric utilities. ${ }^{15}$ The utilities (and regional ISOs) included in this report represent 66 percent of U.S. electricity consumption in the heuristic analysis and 32 percent of consumption in the statistical analysis. Figure 3-1 shows the 67 utilities overlaid on a climate zone map. Utilities are located in all the climate zones except for Zone one, the southern tip of Florida.

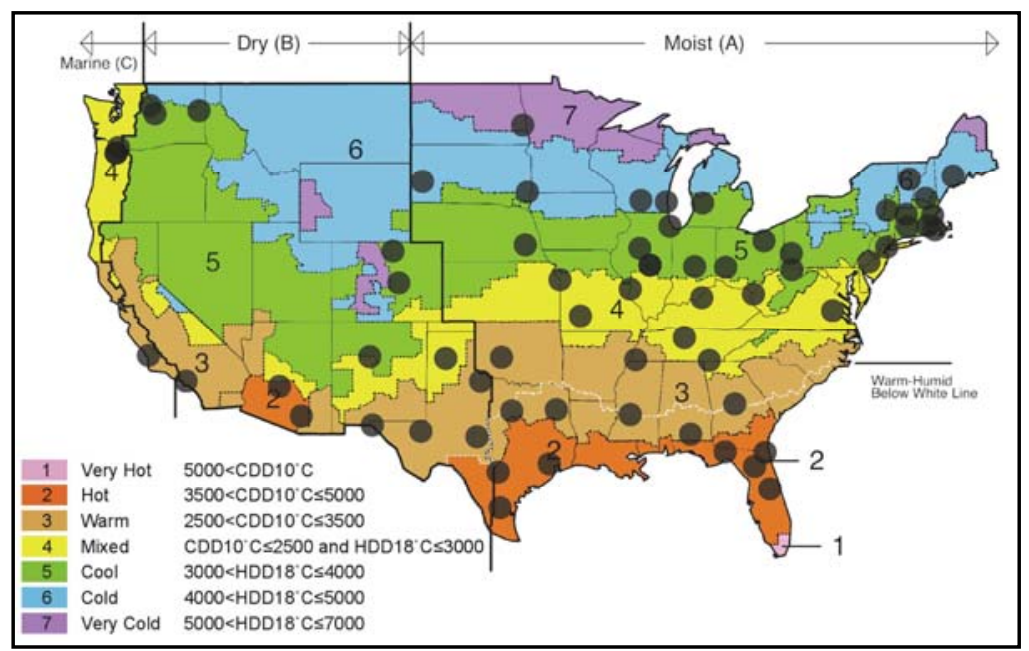

Figure 3-1. Sixty-seven utilities with 2007 data overlaid on Climate Zone map

Heuristic analysis of electricity consumption curves

The heuristic method examined the hourly electricity consumption patterns for 67 electric utilities in 2007 relative to 2006, and used 21-day averages for each hour of the day in the spring

\footnotetext{
${ }^{14}$ The selection of electric utilities for this study aimed to result in a regionally representative collection of utilities, although they were not randomly selected.

${ }^{15}$ Data was obtained from Federal Energy Regulatory Commission reports, independent system operator (ISO) web sites, and directly from utilities.
} 
and seven-day averages for the fall. ${ }^{16}$ This approach is heuristic in the sense that it seeks to predict the 2007 pattern of the average electricity consumption profile that would have occurred without EDST. The observed deviations from a smooth pattern of ratios (in defined ranges of morning and evening hours) are evidence of the impact of EDST. By interpolating between hours deemed to be unaffected by EDST, the average changes in consumption over the EDST periods for spring and fall were calculated.

Figure 3-2 provides an illustration of this approach for Boston's electricity consumption curve. ${ }^{17}$ It shows the ratio, over 21 days, of average hourly electricity consumption in a 24-hour period during both the 2007 spring EDST period and the same period for 2006. Looking at the ratio of $2007 / 2006$ consumption, it is possible to see that for Boston, EDST was likely responsible for the sharp morning increase at around 7:00 a.m. and a substantial reduction during several evening hours. The lines with squares are

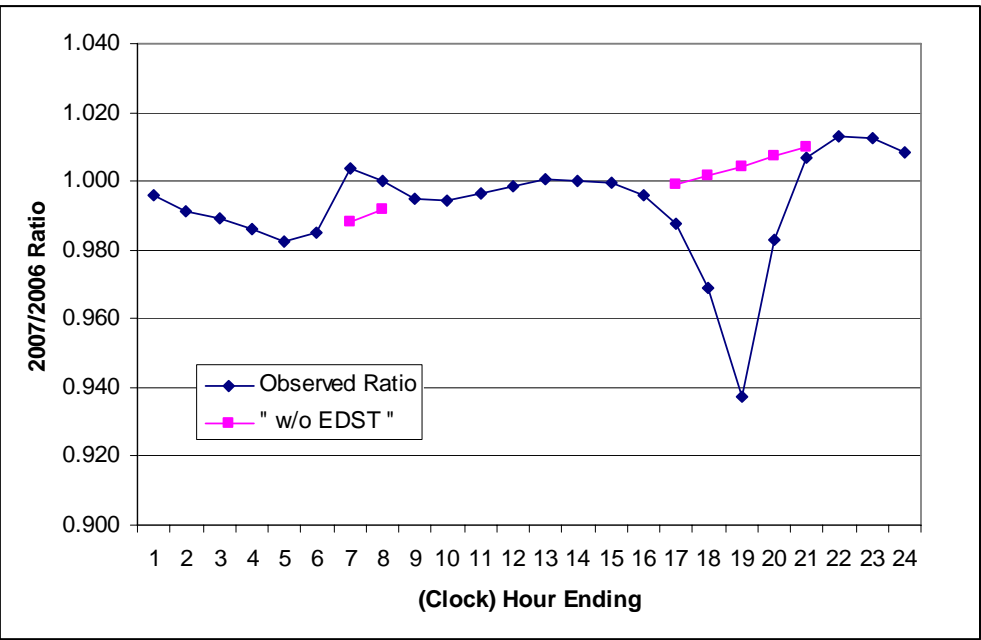

Figure 3-2. Illustration of heuristic approach to estimating impacts, Boston the linearly inserted values of the ratios of consumption for the morning and evening periods. In the morning period, the ratios were interpolated between the hours ending at 6:00 a.m. and 9:00 a.m. In the evening, the interpolation was performed between the hours ending at 4:00 p.m. and 10:00 p.m.

\section{Statistical models: focus on lighting and appliance use}

A statistical approach was developed, using detailed regression models of daily and hourly electricity consumption for as many as 35 utilities located across the United States. ${ }^{18}$ The statistical models account for:

- Electricity consumption growth between 2006 and 2007;

- Seasonal change;

- Day of week (Saturday, Sunday, weekday) and holidays;

\footnotetext{
${ }^{16}$ The spring extension of DST moved the date from the first Sunday in April to the second Sunday in March. For 2007, that totaled 21 days. The fall extension was from the last Sunday in October to the first Sunday in November, seven days.

${ }^{17}$ The data used in the Boston illustrative example comes from the Northeast Massachusetts-Boston sub-region of the New England ISO. As a shorthand descriptor, the study refers to this area as Boston.

${ }^{18}$ Thirty-five utilities, for which data was available, for the spring analysis, and 29 for the fall analysis.
} 
- Temperature (degree-days for both heating and cooling) ${ }^{19}$; and

- Indicator variables to distinguish between the (March and November) EDST and (April and October) DST time periods in 2007 and 2006.

A statistical measure of confidence was determined for the calculated impacts.

The analysis focused on the specific hours where electricity usage was expected to be most influenced by EDST. The morning hours were assumed to be the hours ending in the range between 7:00 a.m. and 8:00 a.m. inclusive. ${ }^{20}$ In the evening, the influenced hours were assumed to extend from 5:00 p.m. through 9:00 p.m. inclusive in the spring and from 5:00 p.m. through 8:00 p.m. inclusive in the fall.

\section{Approaches Used to Examine Traffic Volume and Motor Gasoline Consumption}

The study used two methods of analysis to calculate the impact of EDST on motor gasoline consumption.

One method involved the examination of the two-week averages of motor gasoline consumption for periods before and after DST and EDST. Using weekly data for "motor gasoline supplied" over a 10-year period (1998 to 2007) for both the spring and fall seasons, an analysis was conducted on the impact of daylight time on motor gasoline consumption. ${ }^{21}$ A statistical comparison of the mean values of average gasoline consumption for two weeks before and two weeks after DST and EDST was conducted. The statistical testing evaluates the hypothesis that the mean values of weekly "motor gasoline supplied" are the same (at the 95 percent confidence level) across the transition to or from standard time to DST and EDST. Energy savings were determined by calculating the week-to-week percentage change between the two-week average of before and after weekly "motor gasoline supplied” information.

The second method was a comparison of differences in average week-to-week national traffic volume to determine if there are statistically significant differences in the averages. Daily traffic volume data for the spring was analyzed during the hours most likely to be influenced by EDST. Statistical tests were performed to determine if the mean values of the spring traffic volume changed (at the 95 percent level of confidence) in the weeks before, during, and after EDST. The traffic volume analysis relied upon traffic data that is collected at more than 4,000 continuous traffic-counting locations nationwide. The study used traffic information during the two weeks ${ }^{22}$ before and after Daylight Saving Time in the spring of 2007 and for the same period in 2006.

\footnotetext{
${ }^{19}$ A “degree-day" is a measure of heating or cooling. For example, if the actual temperature is above 65 degrees, the number of heating degrees for that day is zero.

${ }^{20}$ In about one-third of the utilities analyzed, the morning hours displaying the most influence from EDST were those ending at 8:00 a.m. and 9:00 a.m.

21 "Motor gasoline supplied" information is used as a proxy for gasoline consumption. The Technical Documentation for this study provides details.

${ }^{22}$ Using only two weeks of traffic data before and after the Daylight Saving Time minimizes potential influences from long-term trends and seasonal variations within the traffic data series.
} 


\section{Other Considerations}

In addition to the changes in electricity use, motor gasoline use, and primary energy presented in this report, there are other potential energy-related impacts from EDST such as changes in fuel oil and natural gas used for heating in buildings. The previous DST studies that examined fuel oil and natural gas, most notably the 1975 Department of Transportation study, found that DST had less impact on changes in fuel oil and natural gas use in buildings than the changes in electricity consumption. This study did not further examine the fuel oil and natural gas impacts on buildings due to the limited availability of supporting data for analysis of these factors.

In addition, this study did not include an economic analysis of EDST, which compares the relative costs and outcomes, such as cost-benefit or cost-effectiveness. Section 110 of EPAct 2005 directed the Department of Energy to focus only on the impact of EDST on "energy consumption in the United States.” (42 U.S.C. 260a note)

Finally, this study did not analyze any non-energy impacts that might result from EDST, as the focus of Section 110 of the Energy Policy Act of 2005 is only on energy consumption. Potential non-energy impacts include children traveling to school during darkness, traffic accident rates, crime rates, electronics changeover to new EDST dates, airline schedule changes, and agricultural work scheduling. 


\section{References}

Belzer, David B., Stanton W. Hadley, and Shih-Miao Chin, 2008, Impact of Extended Daylight Saving Time on National Energy Consumption: Technical Documentation, prepared for U.S. Department of Energy, Office of Energy Efficiency and Renewable Energy, October. http://www.eere.energy.gov/ba/pba/pdfs/epact_sec_110_edst_technical_documentation_2008.pdf

Department of Energy, 2006, Potential Energy-Saving Impacts of Extending Daylight Saving Time: A National Assessment, Office of Energy Efficiency and Renewable Energy, Washington D.C., October.

Department of Transportation, 1975, The Daylight Saving Time Study: Final Report on the Operation and Effects of Daylight Saving Time, Washington D.C., July.

Department of Transportation, Bureau of Transportation Statistics, 2003, NHTS 2001 Highlights Report, BTS03-05.

Energy Information Administration, Department of Energy, 2008, Weekly Petroleum Status Report, Report Number DOE/EIA-0208(2008-14), Washington D.C.

Federal Energy Regulatory Commission, 2007, FERC eForms - Form 714 Data, Federal Energy Regulatory Commission.

http://www.ferc.gov/docs-filing/eforms/form-714/data.asp

Federal Highway Administration, Department of Transportation, 2007, Traffic Volume Trends, 2006, Washington D.C., December.

Federal Highway Administration, Department of Transportation, 2008, Traffic Volume Trends, 2007, Washington D.C., December.

North American Electric Reliability Council, 2007, Electricity Supply and Demand Database, September.

http://www.nerc.com/ esd/

Public Law No. 89-387, 1966, The Uniform Time Act of 1966, U.S. Government Printing Office, April 13, 1966.

Public Law No. 109-58, 2005, Energy Policy Act of 2005, U.S. Government Printing Office, August 8, 2005.

http://frwebgate.access.gpo.gov/cgi-

bin/getdoc.cgi?dbname=109_cong_public_laws\&docid=f:publ058.109 